Wojciech Gałecki

Instytut Filologii Polskiej

Uniwersytet Wrocławski

e-mail: 299682@uwr.edu.pl

ORCID: 000-0002-7524-8516

\title{
Biografie miast. \\ Zarys problematyki genologicznej w perspektywie hermeneutycznej teorii gatunku
}

Jednym z najbardziej charakterystycznych zjawisk w literaturze współczesnej jest fenomen mieszania się i hybrydyzacji tradycyjnych form gatunkowych. W wyniku tego procesu na niespotykaną dotychczas skalę mnożą się nowe gatunki (a przynajmniej nowe określenia i nazwy genologiczne ${ }^{1}$ ). Jednocześnie we współczesnych badaniach literaturoznawczych wielokrotnie sygnalizowano już problem rozpadu tradycyjnych kategorii genologicznych ${ }^{2}$, które nie są $\mathrm{w}$ stanie poradzić sobie $\mathrm{z}$ tymi nowo powstałymi formami.

Z kolei w rzeczywistości literackiej ostatnich lat - zarówno w literaturoznawstwie, jak i w samej literaturze - można zaobserwować wzrost zainteresowania kategorią przestrzeni, który przyczynił się z jednej strony do zwrotu topograficznego $\mathrm{w}$ nauce o literaturze, a $\mathrm{z}$ drugiej do rozwoju nowych form gatunkowych, przekraczających granice wspomnianej już tradycyjnej genologii. Odnotować też trzeba niespotykany dotąd rozwój i wzrost popularności biografistyki, zarówno naukowej, jak i literackiej ${ }^{3}$. W czasach współczesnych

\footnotetext{
1 Niezwykle istotny podział na przedmioty, pojęcia i nazwy genologiczne, wykorzystany w pracy, został przyjęty zgodnie z ustaleniami Stefanii Skwarczyńskiej. Por. S. Skwarczyńska, Niedostrzeżony podstawowy problem genologii, w: Problemy teorii literatury. Seria 2, red. H. Markiewicz, Wrocław 1987.

2 Na to zjawisko wskazuje m.in. E. Balcerzan w książce Literackość. Modele, gradacje, eksperymenty, Torun 2013.

3 Pisze o tym wielu współczesnych autorów i krytyków literackich [por. A. M. Pycka, Bio-
} 
gatunek biografii przestał być odrzucany przez naukę jako budzący podejrzliwość (źródłem tej podejrzliwości był przede wszystkim jego nieokreślony status, wynikający z właściwej mu skłonności do fabularyzowania opisywanych zdarzeń). W sferze biografistyki literackiej zaś biografia zerwała ostatecznie swoje powiązania $\mathrm{z}$ hagiografią $\mathrm{i}$ w znacznym stopniu ograniczyła wszelkie propagandowe żywotopisarstwo. Najważniejszymi celami tego gatunku stały się obiektywizm i zbliżenie do prawdy. Pojawiło się także miejsce na krytycyzm wobec opisywanego przedmiotu.

Wszystkie te czynniki przyczyniły się w mniejszym lub większym stopniu do powstania zupełnie nieznanej dotychczas formy gatunkowej, łączącej $\mathrm{w}$ sobie aktywne zainteresowanie przestrzenią z podejściem biograficznym, w ramach którego przestrzeń zostaje zmetaforyzowana i odsłania własną, indywidualną historię. Mowa tu o biografii miasta, nieopisanym dotychczas w zasadzie tworze genologicznym, dającym się zaobserwować po raz pierwszy w drugiej połowie XX wieku. To właśnie wówczas powstały pierwsze książki Christophera Hibberta opatrzone tą nazwą gatunkową: London, the Biography of a City z 1969 roku i Rome z roku 1985 z takim samym podtytułem. Choć lista tekstów opublikowanych pod nazwą biografii miasta jest stosunkowo długa, podejmowana tu analiza będzie się opierać przede wszystkim na wyborze trzech najbardziej reprezentatywnych spośród nich: Londynie i Wenecji Petera Ackroyda oraz Tokio Stephena Mansfielda. Nie zawierają one znaczących różnic, mogących zbliżać je do gatunków pokrewnych, takich jak np. monografia historyczna. Jednocześnie w książkach tych dwóch autorów cechy gatunkowe biografii miasta występują w różnym nasileniu, co pozwala dostrzec w jej obrębie dużą różnorodność.

Biografia miasta jest tworem o tyle szczególnym, że próbuje opisać historię elementów nieożywionych w kategoriach ludzkiego życia. Należy jednak podkreślić, że podobna idea nie zrodziła się na gruncie omawianego tutaj gatunku, ale w kręgu badań socjologicznych i antropologicznych. To właśnie tam po raz pierwszy pojawił się koncept tzw. biografii rzeczy. Obszerne rozważania poświęcone takiej biografii przedstawił Tim Dant w pracy Fruitbox / Toolbox: Biography and objects ${ }^{4}$.

Według Danta, aby zacząć mówić o możliwości powstania biografii rzeczy (a więc także, jak można przypuszczać, i miast), należy nadać im i uznać pewien stopień podmiotowości. To przyznanie podmiotowości jest ściśle związane $\mathrm{z}$ naturą biografii jako gatunku, który opisywane obiekty

grafistyka na topie, „Książki: magazyn literacki” 2016, nr 8]. O uznaniu biografistyki w świecie naukowym świadczy m.in. praca R. Jadczaka, Biografistyka $i$ jej miejsce w historii filozofii, „Ruch Filozoficzny" 1995, nr 1.

4 T. Dant, Fruitbox / Toolbox: Biography and objects, „Auto/Biography” 2001, nr 1-2. 
traktuje $z$ jednej strony właśnie jako przedmioty opisu, a $z$ drugiej uznaje je za byt podmiotowy ${ }^{5}$. Inną przyczynę umożliwiającą według Danta powstanie biografii rzeczy stanowi właściwe temu gatunkowi syntetyzujące ujęcie, w ramach którego złożoność i różnorodność zdarzeń zostaje ograniczona i wtłoczona w ramy jednej, spójnej narracji ${ }^{6}$. Z tego również powodu konkretny, pojedynczy obiekt może mieć nieskończoną liczbę biografii, opierającą się na różnych „wersjach” jego życia.

Inną niezwykle interesującą kwestią związaną z tą organicystyczną metaforą jest problem przeniesienia pewnych cech i elementów naturalnych dla życia na grunt dziejów przedmiotów. Zgodnie z ustaleniami Danta ${ }^{7}$ one także w pewien sposób „rodzą się”, doświadczają zdarzeń wpływających na ich stan, a także "umierają", gdy są niszczone lub wyrzucane. Również w wielu tekstach opatrywanych nazwą biografii miast można dostrzec podobne zjawisko, czasami nawet o wiele bardziej rozbudowane: okazuje się, że miasta mogą wypowiadać wojny, gniewać się czy pokonywać kogoś. Wszystkie wymienione wyżej czynniki pozwalają na ustanowienie przedmiotem opisu biografii obiektów nieożywionych lub też abstrakcyjnych. Jak widać, metafory, które na to wpływają, mogą mieć bardzo złożony charakter. Ich przejawami oraz sposobami wykorzystania w biografii miasta zajmę się w dalszej części artykułu.

\section{Biografia miasta jako forma niejednorodna}

Ze względu na złożoność i niejednorodność biografii miasta niezwykle trudno jest znaleźć dla niej odpowiednią metodę opisu. Niewątpliwie jest to jeden $\mathrm{z}$ tych gatunków, które idą w poprzek tradycyjnych podziałów i przyczyniają się do wielokrotnie już sygnalizowanego we współczesnej genologii zjawiska rozpadu tradycyjnych gatunków literackich. Z tego samego powodu błędnym pomysłem wydaje się zamiar analizy tego gatunku przy wykorzystaniu metod wypracowanych już przez tradycyjną genologię. Jakakolwiek próba jednoznacznego określenia szkieletu gatunkowego (a więc tym samym ustalenia spójnego paradygmatu) byłaby tu zadaniem niewykonalnym i zbytecznym z co najmniej dwóch powodów. Przede wszystkim należy wskazać na dużą wewnętrzną niejednorodność tekstów określanych mianem ",biografii miast”, a także na ich bliskie związki z tekstami należą-

\footnotetext{
5 Tamże, s. 13.

6 Tamże, s. 11.

7 Tamże, s. 3.
} 
cymi do takich gatunków, jak reportaż, przewodnik czy monografia historyczna. Warto wskazać tutaj także na inne trudności, wynikające z niejednoznacznego charakteru biografistyki. Podstawowym problemem jest sprawa podziału na biografistykę naukową i literacką ${ }^{8}$.

Wokół biografii miasta piętrzy się wiele niejednoznacznych wskazówek dotyczących jej charakteru. Nie oznacza to jednak, że próba genologicznego określenia tego gatunku jest z góry skazana na porażkę. Aby tego dokonać, należy poszukać takiej perspektywy, która pozwoliłaby spojrzeć na gatunek w sposób zupełnie odmienny od tradycyjnego, uwzględniający procesy zachodzące w literaturze współczesnej, które polegają na wychodzeniu nowych utworów poza granice wyznaczane przez tradycyjną genologię. Krótko mówiąc, ta nowa perspektywa powinna umożliwić przeprowadzenie granic gatunkowych według innych zasad, zgodnych ze stanem rzeczywistym. Wydaje się, że podobne spojrzenie zapewnia teoria genologii hermeneutycznej Stanisława Balbusa ${ }^{9}$, która zdaje się być najbardziej przekonującym rozwiązaniem dla problemów współczesnej genologii. Z jednej strony potrafi ona uchwycić i w sposób spójny zebrać utwory przekraczające tradycyjne podziały ustalone $\mathrm{w}$ paradygmatycznym myśleniu o gatunku, z drugiej zaś wyznacza na tyle elastyczne zasady klasyfikacyjne, że są one w stanie objąć dzieła o charakterze niejednorodnym, łączące w sobie niekiedy kilka istniejących form gatunkowych.

Przed przystąpieniem do szczegółowej analizy gatunku należy jednak wspomnieć o pewnej szczególnej orientacji badawczej, która może okazać się bardzo użyteczna przy rozwiązywaniu problemów dotyczących biografii miast. Jak wspomniano we wstępie, rozwój tego gatunku przypada w dużej mierze na okres zwrotu przestrzennego $w$ literaturoznawstwie, a także, jak się wydaje, był przez ten zwrot inspirowany. Wypracowane wówczas metody badawcze mogą więc być tu $\mathrm{z}$ powodzeniem stosowane nie tylko ze względu na przedmiot opisu tych biografii, ale także na wspólny z nimi rodowód. Na szczególną uwagę zasługują zwłaszcza dwie z nich: geokrytyka Bertranda Westphala oraz koncepcja auto/bio/geo/grafii Elżbiety Rybickiej ${ }^{10}$.

\footnotetext{
8 Kwestię tę omawiają szerzej m.in. M. Jasińska, Zagadnienia biografii literackiej, Warszawa 1970 oraz I. Adamczewska, Biografia reporterska w ujęciu komunikacyjnym na przykładzie książek Angeliki Kuźniak, „Annales Universitatis Paedagogicae Cracoviensis. Studia Poetica” 2016, t. 4, s. $164-185$.

9 S. Balbus, Zagłada gatunków, „Teksty Drugie” 1999, nr 6, s. 25-39.

10 Opis tych orientacji badawczych można znaleźć w pracy Elżbiety Rybickiej Geopoetyka. Przestrzeń i miejsce we współczesnych teoriach i praktykach literackich, Kraków 2014. Mowa tu o rozdziałach Geokrytyka i komparatystyka oraz Auto/bio/geo/grafie [s. 69-277].
} 
Do największych zalet geokrytyki w kontekście badań nad omawianym gatunkiem należy szczególne ujęcie charakteru miejsca, oglądanego $\mathrm{w}$ taki sam sposób, w jaki jest postrzegane w biografiach miast - według kryteriów ściśle geograficznych, wyróżniających konkretną przestrzeń spośród pozostałych. Inną ważną cechą geokrytyki byłoby jej komparatystyczne nastawienie, które często jest także cechą biografii miasta. Twórcy tego gatunku często zderzają ze sobą różne świadectwa i punkty widzenia, aby w możliwie najwyższym stopniu zbliżyć się do prawdy. Z kolei koncepcja auto/bio/geo/grafii Elżbiety Rybickiej dotyka bezpośrednio omawianej tutaj formy gatunkowej. Badaczka rozważa problem dzieł o charakterze biograficznym, w których narracja jest uporządkowana przestrzennie - $\mathrm{w}$ ich ramach „przestrzenie geograficzne i spacjalizacja są zarówno przedmiotem, jak i metodą oraz narzędziem operacyjnym" ${ }^{11}$. Na jeden z ilustrujących to zjawisko przykładów autorka wybiera biografię Petera Ackroyda poświęconą Londynowi ${ }^{12}$. Przy okazji czyni w tym miejscu kilka interesujących rozpoznań dotyczących natury biografii miasta. Spostrzeżenia te są bardzo przydatne $\mathrm{w}$ kontekście omawianych tutaj problemów i w dalszej części pracy posłużą jako punkt odniesienia dla bardziej szczegółowej analizy.

\section{Interpretacyjne sygnały $\mathrm{w}$ obrębie tekstu}

Na początku szczegółowych rozważań dotyczących biografii miasta należy przyjrzeć się problemom podstawowej wagi. Dotyczą one kwestii niezależności gatunkowej tej formy, a także jej ostatecznego genologicznego przyporządkowania. Warto w tym miejscu odwołać się do założeń hermeneutycznej teorii gatunku. Jak wskazuje Stanisław Balbus, w tekście mogą wystąpić zasadniczo dwa rodzaje "wskazówek” dotyczących genologicznej interpretacji tekstu. Należą do nich odautorskie kwalifikacje gatunkowe, zamieszczane na ogół w podtytułach dzieł oraz pewne charakterystyczne dla danego gatunku elementy, potwierdzające kwalifikację uczynioną wcześniej przez autora. Warto w tym miejscu zauważyć, że nazwa genologiczna „biografia miasta" zawsze jest bezpośrednio wyrażona w tytule tekstu i w zasadzie nie została jeszcze wykorzystana przez krytykę i czytelników do określenia jakiegoś dzieła w sposób „zewnętrzny”, a więc nie uzyskała jeszcze w pełni statusu pojęcia genologicznego ${ }^{13}$.

\footnotetext{
11 Tamże, s. 281.

12 P. Ackroyd, Londyn. Biografia, przeł. T. Bieroń, Poznań 2011.

13 Chodzi tutaj o to, że poza tekstami, które są określane (właśnie w tytułach) jako biografie
} 
Pozostaje jednak jeszcze drugi z kluczowych dla teorii Balbusa elementów, a więc kwestia występowania w poszczególnych dziełach wskaźników, które niejako immanentnie narzucają określony sposób interpretacji tekstu.

Omówienie tych wskaźników wypadnie rozpocząć od przywołania jednego z rozpoznań Elżbiety Rybickiej dotyczących auto/bio/geo/grafii. Badaczka stwierdza, że podstawowym warunkiem dla biografii miasta jest wykorzystanie w jego opisie antropomorfizacyjnej metafory, jego naturalizacja. Trzeba także pamiętać, że podobne zjawisko miał na myśli Tim Dant w przywoływanej na początku pracy. Zgodnie ze spostrzeżeniami Rybickiej, w Londynie Petera Ackroyda można dostrzec organicystyczny, XIX-wieczny sposób patrzenia na miasto.

Przyjrzyjmy się więc teraz tym wszystkim metaforyzacyjnym zabiegom dokładniej. Warto zauważyć, że wielu autorów tego typu tekstów wprowadza wspomnianą metaforę $\mathrm{w}$ różnych pozatekstowych komentarzach, posłowiach i wstępach. Niektórzy wplatają ją nawet w przestrzeń organizacji tekstu, jak na przykład Peter Ackroyd, w którego Wenecji ${ }^{14}$ znajdują się rozdziały zatytułowane Korzenie i Miasto żywe. Wydaje się nawet, że twórcy uświadamiając sobie gatunkową niejednorodność swoich dzieł, wskazują w komentarzach na formę gatunkową, według której należy ich tekst interpretować.

Warto zauważyć, że stopień wyeksponowania antropomorfizacyjnej metafory jest różny $\mathrm{w}$ zależności od indywidualnych celów autora biografii. Może więc stać się ona jednym z podstawowych założeń książki (tak jest w przypadku wspominanego wcześniej Londynu) lub zająć miejsce jednego z wielu elementów narracji, na tyle jednak rozpoznawalnego i szczególnego, by wpływać $\mathrm{w}$ istotny sposób na jej przebieg (tak dzieje się m.in. w przypadku Tokio ${ }^{15}$ Stephena Mansfielda). Można jednak przyjąć, że idea miasta jako bytu obdarzonego życiem jest obecna w mniejszym lub większym stopniu także w pozostałych dziełach opatrzonych tą nazwą gatunkową.

Próba pokazania miasta jako żywego organizmu jest widoczna nie tylko w odautorskich komentarzach, w pewien sposób „modelujących” sposób czytania. Znajduje ona swoje potwierdzenie także na powierzchni tekstu, w której od czasu do czasu pojawiają się elementy „przypominające” o zaprojektowanym przez autora sposobie odczytywania. Warto przyjrzeć się tym elementom dokładniej.

miast, nie można znaleźć żadnego opracowania albo recenzji, która wykorzystywałaby tę nazwę do gatunkowego określenia tekstu. Dokładniej rzecz ujmując, chodzi tu np. o sytuację, w której krytyk albo recenzent Miedzianki Filipa Springera określiłby ją jako biografię miasta, niezależnie od autorskiej intencji.

14 P. Ackroyd, Wenecja. Biografia, przeł. T. Bieroń, Poznań 2015.

15 S. Mansfield, Tokio. Biografia, przeł. M. Moskal, Kraków 2018. 
Sposób prezentacji i stopień ich rozbudowania mogą być bardzo różne w zależności od strategii obranych przez autorów. Niektórzy z nich powracają do tej idei za pomocą rozbudowanych metafor, wpisujących poszczególne miejsca, wydarzenia i procesy związane z miastem w drogę jego „życia”. Opisując Wenecję, Peter Ackroyd stwierdza w pewnym momencie, że miasto:

wchłonęło wyspy, z których się składało. Jej kanały i inne drogi wodne tworzyły system pokarmowy. Wszystko chce nadać kształt swojej naturze. Liście drzew dążą do uzyskania przypisanego im kształtu ${ }^{16}$.

Innym zabiegiem przypominającym o antropomorficznym punkcie widzenia jest cytowanie różnych dzieł i opracowań poświęconych danemu miastu, potwierdzających sposób patrzenia przyjęty przez autora:

Kanały były żyłami, a samo miasto sercem, jak napisał w 1549 roku Cristoforo Sabbadino. [...] Henry James, zawsze podatny na subtelności i zawiłości osobistej wrażliwości, powiedział, że Wenecja "wydaje się uosabiać samą siebie, stawać się ludzką, czującą i świadomą naszych emocji" ${ }^{17}$.

Poza tym zdarzają się wyrażenia mówiące o żywotności miasta w sposób eksplicytny, takie jak stwierdzenie Stephena Mansfielda, że „współczesne Tokio - pomimo swej oszałamiającej złożoności - z powodzeniem funkcjonuje jako pojedynczy, stabilny organizm"18.

Kolejnym niezwykle ważnym elementem, decydującym $\mathrm{z}$ jednej strony o literackości biografii miasta, a $\mathrm{z}$ drugiej związanym $\mathrm{z}$ przekształceniem wzorca zawartego w biografii tradycyjnej, jest porządek narracji, według którego opowiadane są kolejne wydarzenia $\mathrm{z}$ życia miasta. $\mathrm{Z}$ jakiego powodu problem literackości ma tak duży związek z porządkiem narracji? Zgodnie z cytowanym wyżej stwierdzeniem Tima Danta dotyczącym przejawów literackości w próbie opowiedzenia historii danej rzeczy, a także według opinii Marii Jasińskiej, zgodnie z którą "ujęcie przedmiotu jako zrozumiałej a zarazem niepowtarzalnej, tej oto, a nie innej całości to typowe ujęcie sztuki"19, zawarcie określonego przedmiotu - $\mathrm{w}$ tym przypadku miasta - w porządku narracji decyduje jednocześnie o jego literackości. Trzeba także pamiętać o tym, że sposób opowiadania niekoniecznie musi opierać się na porządku chronologicznym lub, w szerszym ujęciu, czasowym. Narracja może układać

\footnotetext{
16 P. Ackroyd, Wenecja, s. 217.

17 Tamże.

18 S. Mansfield, Tokio, s. 219.

19 M. Jasińska, Zagadnienia biografii literackiej, s. 24-25.
} 
się np. wokół kolejnych cech danego obiektu lub związanych z nim kręgów tematycznych. Warto także zauważyć, że na różnych jej poziomach może przebiegać według różnych schematów.

\section{Porządek narracji}

Aby rozpocząć rozważania na temat porządku narracji w biografii miasta, warto powrócić do rozpoznań dotyczących Londynu Petera Ackroyda, poczynionych w ramach teorii auto/bio/geo/grafii Elżbiety Rybickiej. Opierając się na wywodach autora książki, Rybicka stwierdza, że linearny porządek czasu został w niej uprzestrzenniony. Należy dodać, że w dużej mierze stało się tak również z porządkiem narracji. W swoich książkach Ackroyd swobodnie stawia przed czytelnikiem obrazy tych samych miejsc pochodzące z różnych, czasami bardzo odległych epok, krzyżuje je ze sobą, niekiedy odwraca dotyczącą ich chronologię, aby zbliżyć się do ich istoty, wpisać je do własnej interpretacji historii miasta.

Na szerszym planie można dostrzec jednak funkcjonowanie innego porządku, w ramach którego dzieje miasta nie są już opowiadane według schematu linearnego lub przestrzennego, ale zostają skupione wokól jego charakterystycznych cech i obiektów (instytucji, architektury, mieszkańców, świąt). Wskazują na to również informacje zawarte w tytułach poszczególnych rozdziałów książek pisarza, mówiące o kolejnych elementach wyróżnionych przez autora i poddanych przez niego interpretacji. W wielu przypadkach Ackroyd wybiera jeden z tych elementów lub procesów i dokładnie omawia jego strukturę, wygląd i funkcjonowanie, zarówno w związku z czasem jego występowania, jak i właściwym mu miejscem w przestrzeni miasta. Taki sposób prowadzenia narracji można uznać za swego rodzaju porządek tematyczny, w którym autor stara się przedstawić życie danego miasta za pomocą opowieści o jego cechach i osobliwościach. Należy jednak podkreślić, że funkcjonowanie i przenikanie się różnych porządków narracji nie oznacza zanegowania temporalności opowiadania. Zgodnie ze spostrzeżeniem Elżbiety Rybickiej jest raczej próbą zaprezentowania czytelnikowi innego spojrzenia na problem czasu, propozycją przyjęcia perspektywy przestrzennej lub tematycznej $w$ jego pojmowaniu ${ }^{20}$.

W przypadku biografii Petera Ackroyda można mówić o dwóch niezależnych od siebie sposobach prowadzenia narracji, obecnych na różnych poziomach opowiadania. $Z$ jednej strony widać $w$ nich nadrzędny porzą-

20 E. Rybicka, Geopoetyka, s. 281. 
dek tematyczny, w którym autor opowiada o kolejnych zdarzeniach z życia miasta, grupując je wokół jednego tematu, którego dotyczą. Z drugiej zaś strony wewnątrz tych opowieści zdarzenia historyczne zostają uprzestrzennione i pozbawione sztywnego, chronologicznego charakteru:

Pepys opisuje tłum żołnierzy, którzy „stali, krzycząc i domagając się wolnego Parlamentu i żołdu”, a latem 1667 roku odnotowuje: „Wczoraj w Westminster lud jawnie wołał po ulicach: «Dawać Parlament! Parlamentu chcemy!»". Rok później wybuchły rozruchy w Poplar i Moorfields, a bramy nowego więzienia w Clerkenwell szturmowali ludzie chcący uwolnić tych, którzy zgodnie ze starym londyńskim zwyczajem burzyli domy rozpusty ${ }^{21}$.

O ile pierwszy ze wskazanych porządków jest charakterystyczny tylko dla pewnej grupy twórców gatunku, o tyle drugi występuje niemal we wszystkich gatunkowych reprezentacjach, stanowiąc jeden $\mathrm{z}$ ich podstawowych chwytów.

Jak się okazuje, praktyka wykorzystywania charakterystycznych cech i tematów związanych $\mathrm{z}$ danym miejscem jako kluczy interpretacyjnych, pozwalających na uzyskanie spójnego obrazu miasta jest znana nie tylko Peterowi Ackroydowi. Można ją dostrzec również w pracach pozostałych pisarzy, m.in. w Gdańsku Petera Olivera Loewa ${ }^{22}$. Autorzy biografii miast zwykle odsłaniają swój sposób patrzenia na miasto we wstępach lub początkowych rozdziałach książki, by opisywane później wydarzenia wykorzystywać do umacniania przyjętego punktu widzenia. $Z$ tego powodu wiele biografii miast przypomina rozprawy mające za zadanie obronę postawionej tezy.

\section{Biografia miasta $\mathrm{w}$ ujęciu geokrytyki}

Po próbie ujęcia pewnych właściwości biografii miasta z perspektywy auto/bio/geo/grafii warto przyjrzeć się jej przez pryzmat geokrytyki - drugiego ze wspomnianych kierunków badawczych mieszczących się w spektrum geopoetyki. Główną sferę działań tego nurtu stanowią badania porównawcze różnych tekstów kultury dotyczących jednego, konkretnego miejsca. Badania te pozwalają na zderzenie ze sobą różnorodnych punktów widzenia i uzyskanie wielowymiarowego oglądu danej przestrzeni. Prace inspirowane

21 P. Ackroyd, Londyn, s. 412.

22 P.O. Loew, Gdańsk. Biografia miasta, przeł. J. Górna, Gdańsk 2013. 
geokrytyką mają charakter przede wszystkim komparatystyczny. Na pierwszy rzut oka wydaje się więc, że biografie miast powinny stanowić raczej materiał źródłowy dla badań geokrytycznych, niż poddawać się dogłębnej analizie przy wykorzystaniu swoistych dla nich metod.

Okazuje się jednak, że w niektórych wypadkach książki należące do omawianej tu formy gatunkowej rzeczywiście pozwalają się oglądać indywidualnie, w pewien sposób „od środka”, z perspektywy geokrytyki. Chodzi tu o takie biografie miast, których autorzy dla uzyskania maksymalnego obiektywizmu, wykorzystują ogromną liczbę tekstów poświęconych opisywanemu miejscu. Źródła te mają bardzo różnorodny charakter i nie są jedynie kronikarskimi zapiskami mieszkańców danego miasta. Obejmują teksty tworzone zarówno przez przyjezdnych, jak i autochtonów. Ich twórcy wywodzą się ze wszystkich grup społecznych: są wśród nich artyści, kupcy, przedstawiciele władz, socjologowie, historycy i osoby żyjące na marginesie społecznym. Można więc uznać biografie miast za małe geokrytyczne antologie, zderzające ze sobą różne przekazy dotyczące miasta, aby wydobyć z nich jego spójny obraz.

Przykładami podobnych antologii mogą być Wenecja i Londyn Petera Ackroyda, których autor gęsto przeplata biografie różnymi intertekstualnymi nawiązaniami, szukając w nich potwierdzenia dla swojego sposobu interpretacji dziejów miasta:

A potem przez pryzmat commedia dell'arte zaczęto postrzegać rzeczywistych ludzi i rzeczywiste wydarzenia. [...] Samych Wenecjan kpiąco nazywano „pantaloni”. Byron dostrzegł w nich „naiwność i komizm Pantalone”. [...] Casanova opisuje, jak włożył strój Pierrota i „zaczął w nim chodzić jak dureń [...]". Wenecjanin bez chwili wahania mógł zostać aktorem ${ }^{23}$.

Ackroyd konfrontuje i miesza w tym miejscu ze sobą przekazy pochodzące z odległych epok, napisane przez różnych autorów, aby wykorzystać ich słowa dla zobrazowania pewnej dostrzeżonej przez siebie prawdy (w tym wypadku dotyczącej teatralności w życiu Wenecjan). Warto zauważyć także, że takie intertekstualne operacje nie obejmują wyłącznie tekstów literackich i opracowań naukowych. Świadomie lub nieświadomie, zgodnie z duchem geokrytyki, biografowie miast sięgają po dzieła pochodzące z różnych dziedzin sztuki, często posługując się ekfrazą. Podobne praktyki można dostrzec w większości książek określanych jako biografie miast, oczywiście w większym lub mniejszym nasileniu. Najbardziej reprezentatywnym przykładem jest tu chyba Tokio Stephena Mansfielda.

23 P. Ackroyd, Wenecja, s. 142. 
W związku z geokrytycznym punktem widzenia wypada też wspomnieć o innej właściwej temu kierunkowi metodzie, ujawniającej się w biografiach miast równie często jak ich komparatystyczna orientacja i bezpośrednio na nią wpływającej. Chodzi tu mianowicie o zjawisko multifokalizacji ${ }^{24}$.

Zgodnie z ustaleniami Bertranda Westphala, zasada multifokalizacji w geokrytyce może być rozpatrywana na dwóch poziomach: relacji między obserwowanym i obserwującym oraz na płaszczyźnie punktu widzenia obserwatora, jego tożsamości ${ }^{25}$. Znowu, podobnie jak w przypadku ujęcia komparatystycznego, biografia miasta pełni jednocześnie dwie funkcje - zawiera w sobie punkt widzenia pojedynczego obserwatora (narratora biografii) i jest zbiorem obserwacji uczynionych przez narratorów przywoływanych tekstów.

Warto w tym miejscu przyjrzeć się każdemu ze wskazanych poziomów z osobna. Punkt widzenia przyjmowany przez narratorów (autorów) biografii miast jest związany $\mathrm{z}$ ich tożsamością, a więc $\mathrm{w}$ każdym przypadku będzie się różnił od pozostałych możliwych perspektyw. Z drugiej strony jednak, w przypadku jednego i tego samego autora punkt widzenia może ulegać zmianom (np. w sytuacji, w której autor w jednej ze swoich książek zajmuje się życiem swojego rodzinnego miasta, a w innej opisuje miasto, w którym jest przyjezdnym - tak dzieje się w przypadku Londynu i Wenecji Petera Ackroyda). Autor biografii miasta może więc wchodzić w wiele różnych „ról”: turysty, miłośnika ziemi ojczystej, imigranta, autochtona, potomka kolonizatorów. $Z$ tego powodu każda $\mathrm{z}$ biografii miast ma w pewnym stopniu subiektywny charakter, który pozwala odróżnić je od opracowań naukowych, posługujących się zawsze tym samym, silnie zobiektywizowanym rodzajem dyskursu.

Pozycje zajmowane przez narratorów biografii miast pozwalają się uporządkować także według innego kryterium określania fokalizacji. Chodzi tu o podział na trzy główne grupy - endogeniczną, egzogeniczną i allogeniczną - w których można umiejscowić każdy narracyjny punkt widzenia. Do grupy endogenicznej należą ci autorzy, którzy opisują miasto z pozycji jego mieszkańca, a do egzogenicznej tacy, którzy oglądają je oczami osoby z zewnątrz (turysty, przyjezdnego). W grupie allogenicznej znajdują się natomiast wszyscy ci, których nie można łatwo zakwalifikować do żadnej z powyższych grup, w pewien sposób rozdarci pomiędzy nimi (np. imigranci, zesłańcy, przesiedleńcy). Zgodnie z tym podziałem, Peter Ackroyd w swojej książce poświęconej rodzinnemu Londynowi zajmuje pozycję narratora endogenicz-

\footnotetext{
24 E. Rybicka, Geopoetyka, s. 71.

25 B. Westphal, Geocriticism: real and fictional spaces, przeł. R. T. Tally Jr., New York 2011, s. 122-131 (wyd. francuskie: La Géocritique. Réel, fiction, espace, Paris 2007).
} 
nego, w przypadku biografii Wenecji natomiast jest narratorem egzogenicznym, opisującym miasto z perspektywy turysty-podróżnika. Ta zmiana punktów widzenia w narracji niesie za sobą oczywiste różnice w strukturze i cechach obu tekstów - w porównaniu z biografią Wenecji, książka dotycząca Londynu wydaje się mniej krytyczna, ale za to bardziej rozbudowana i subiektywna.

Trzeba również stwierdzić, że biografia miasta, naturalnie zawierająca liczne intertekstualne nawiązania i przytoczenia pochodzące z różnych dzieł, sama jest zbudowana na zasadzie multifokalizacji. Jedną z najważniejszych intencji dążących do obiektywizmu autorów tej formy gatunkowej jest "skorzystanie" z jak największej liczby dostępnych punktów widzenia. Widać to m.in. $w$ takich fragmentach jak ten:

W poezji tej epoki roi się od odniesień i obrazów ciemnego miasta, by wymienić tylko Dowsona, Lionela Johnsona, George'a Mereditha i Tennysona. Wspominając młodzieńcze lata, kiedy mieszkał w Londynie, Rudyard Kipling napisał: „To tutaj po raz pierwszy noc uderzyła mi do głowy". [...] Dla Charlesa Dickensa nocne przechadzki były lekarstwem na osobiste bolączki. [...] W London Nights (1925) czytamy: „Przeszłość ma większą władzę nad nocą niż nad dniem” 26.

Co więcej, celowe pominięcie lub wybór któregoś z punktów widzenia także może mieć swoje znaczenie. Twórca biografii miasta może dowolnie selekcjonować dostępne sobie źródła i pomijać te, które wydają mu się nierzetelne lub po prosu nie odpowiadają proponowanej przez niego interpretacji dziejów miasta. Może także stworzyć listę takich źródeł, które w sposób jednoznaczny będą umacniać jego punkt widzenia i z zasady odrzucać wszystkie pozostałe. Wskazuje to na ogromne możliwości subiektywizowania opisu w biografii miasta.

Przedstawiona tutaj analiza nie wyczerpuje wszystkich zagadnień związanych z biografią miasta jako gatunkiem. Szczególnie interesujące mogłoby okazać się spojrzenie na tę formę z punktu widzenia koncepcji somaestetyki Richarda Shustermana ${ }^{27}$. Stosowana w biografiach miast antropomorfi-

\footnotetext{
26 P. Ackroyd, Londyn, s. 477-479.

27 Omówienie tej koncepcji można znaleźć m.in. w pracach Richarda Schustermana: Somaesthetics: A Disciplinary Proposal, "The Journal of Aesthetics and Art Criticism” 1999, Vol. 57, No. 3; Body and the Arts: The Need for Somaesthetics, "Diogenes” 2013, nr 59; Introducing Somaesthetics: Aims and Challenges, "Aesthetics in Action. International Yearbook of Aesthetics”, Vol. 18.
} 
zacyjna metafora często wykorzystuje elementy obrazowania somatycznego. Obrazowanie takie zdaje się poddawać łatwej interpretacji w ramach nurtu somaestetyki analitycznej (analytic somaesthetics). W jej kontekście zarysowują się także inne problemy badawcze: zagadnienie płci miasta (rozpatrywane także z perspektywy genderowej) oraz problem tożsamości etnicznej miasta. Bardzo ciekawym zadaniem wydaje się także ewentualna próba porównania biografii miasta $\mathrm{z}$ gatunkami o podobnej tematyce, takimi jak reportaż i przewodnik turystyczny. Porównanie takie pozwoliłoby lepiej zrozumieć cechy odróżniające biografie miast od tekstów należących do wskazanych gatunków. Wyraźniej uwidoczniłaby się wówczas także niezależność gatunkowa biografii miast. Jak można przypuszczać, podstawowe różnice między omawianą tu formą a wymienionymi gatunkami będą dotyczyły wykorzystywanych w nich porządków narracji oraz narratorskich perspektyw. Podobne porównanie, mogące obejmować także inne gatunki należące do literatury miejskiej, jest jednak punktem wyjścia dla osobnych rozważań.

\section{Bibliografia}

Ackroyd Peter (2011), Londyn. Biografia, przeł. T. Bieroń, Poznań: Zysk i S-ka. Ackroyd Peter (2015), Wenecja. Biografia, przeł. T. Bieroń, Poznań: Zysk i S-ka.

Adamczewska Izabella (2016), Biografia reporterska w ujęciu komunikacyjnym na przykładzie ksiażek Angeliki Kuźniak, „Annales Universitatis Paedagogicae Cracoviensis. Studia Poetica", t. 4, s. 164-185.

Balbus Stanisław (1999), Zagłada gatunków, „Teksty Drugie”, nr 6, s. 25-39.

Balcerzan Edward (2013), Literackość. Modele, gradacje, eksperymenty, Toruń: Wydawnictwo Naukowe Uniwersytetu Mikołaja Kopernika.

Dant Tim (2001), Fruitbox/ Toolbox: Biography and objects, "Auto/Biography", Vol. 9, No. $1-2$, s. 11-20.

Jadczak Ryszard (1995), Biografistyka i jej miejsce w historii filozofii, „Ruch Filozoficzny”, nr 1, s. 85-90.

Jasińska Maria (1970), Zagadnienia biografii literackiej, Warszawa: PWN.

Loew Peter Oliver (2013), Gdańsk. Biografia miasta, przeł. J. Górna, Gdańsk: Instytut Kultury Miejskiej.

Mansfield Stephen (2018), Tokio. Biografia, przeł. M. Moskal, Kraków: Wydawnictwo Uniwersytetu Jagiellońskiego.

Pycka Anna Małgorzata (2016), Biografistyka na topie, „Książki: magazyn literacki”, nr 8, s. 12-17.

Rybicka Elżbieta (2014), Geopoetyka. Przestrzeń i miejsce we wspótczesnych teoriach i praktykach literackich, Kraków: Universitas.

Shusterman Richard (1999), Somaesthetics: A Disciplinary Proposal, „The Journal of Aesthetics and Art Criticism", Vol. 57, No. 3, s. 299-313. 
Shusterman Richard (2013), Body and the Arts: The Need for Somaesthetics, "Diogenes”, nr 59, s. 7-20.

Shusterman Richard (2014), Introducing Somaesthetics: Aims and Challenges, "Aesthetics in Action. International Yearbook of Aesthetics", Vol. 18, s. 111-116.

Skwarczyńska Stefania (1967), Niedostrzeżony podstawowy problem genologii, w: Problemy teorii literatury, red. H. Markiewicz, Wrocław: Ossolineum, s. 145-164.

Westphal Bertrand (2011), Geocriticism: real and fictional spaces, przeł. Robert T. Tally Jr., New York: Palgrave Macmillan.

\title{
City Biographies: \\ Genealogical Problems in the Hermeneutic Theory of Genre
}

\begin{abstract}
The article addresses the most important problems related to the biography of a city, including its generic category. It appears that the best way to approach these difficulties is through the hermeneutic theory of genre. In order to define the key interpretative methodologies of the genre, the author draws on the geocritical concepts developed by Elżbieta Rybicka (the theory of auto/bio/geo/graphy) and Bertrand Westphal.
\end{abstract}

Keywords: genre, biography, geocriticism, auto/bio/geo/graphy, multifocal perspective, spatial turn 